\title{
Comparison of Maternal Serum Levels and Placental mRNA Levels of Dickkopf-1 in Preeclamptic and Normal Pregnant Women at Delivery
}

\section{Vergleich von Dickkopf-1-Konzentrationen in mütterlichem Serum und planzentärem mRNA in Frauen mit Präeklampsie und Frauen mit normaler Schwangerschaft bei der Geburt}

(C) 98

Authors

Mariz Kasoha, Zoltan Takacs, Lena Fackiner, Christoph Gerlinger, Panagiotis Sklavounos, Julia Radosa, Erich-Franz Solomayer, Amr Hamza

Affiliation

Department of Gynecology, Obstetrics and Reproductive Medicine, University Medical School of Saarland, Homburg/ Saar, Germany

Key words

preeclampsia, Wnt/ $\beta$-catenin signaling, Dickkopf-1 (DKK1), serum, placenta, pathogenicity

Schlüsselwörter

Präeklampsie, Wnt/ $\beta$-Catenin-Signalisierung, Dickkopf-1

(DKK1), Serum, Plazenta, Pathogenität

received

12.4. 2021

accepted after revision

22.7. 2021

Bibliography

Geburtsh Frauenheilk 2021; 81: 1247-1255

DOI 10.1055/a-1557-1234

ISSN 0016-5751

(c) 2021. The Author(s).

This is an open access article published by Thieme under the terms of the Creative Commons Attribution-NonDerivative-NonCommercial-License, permitting copying and reproduction so long as the original work is given appropriate credit. Contents may not be used for commercial purposes, or adapted, remixed, transformed or built upon. (https://creativecommons.org/licenses/by-nc-nd/4.0/)

Georg Thieme Verlag KG, Rüdigerstraße 14,

70469 Stuttgart, Germany

Correspondence

Dr. rer. nat. Mariz Kasoha

Department of Gynecology, Obstetrics and Reproductive

Medicine, University Medical School of Saarland

Kirrbergerstraße 100, Geb. 9, 66421 Homburg/Saar, Germany

mariz.kasoha@uks.eu

\section{ABSTRACT}

Background Preeclampsia remains a major cause of perinatal and maternal mortality and morbidity worldwide. Wnt/ $\beta$ catenin signaling is known to be critically involved in placenta development processes. Dickkopf-1 (DKK1) is a key regulator of this transduction pathway. The aim of this study is to compare maternal serum DKK1 levels and placental mRNA levels of $D K K 1$ and $\beta$-catenin in preeclamptic and normal pregnant women at delivery.

Methods The present study included 30 women with preeclampsia and 30 women with normal pregnancy. Maternal serum DKK1 levels were measured by ELISA. Placental mRNA levels of DKK1 and $\beta$-catenin were detected using RT-PCR.

Results Decreased maternal serum DKK1 levels were associated with worse maternal and fetal complications including HELLP syndrome, determination of one or more pathological symptom and IUGR diagnosis. No significant difference in maternal serum DKK1 levels was reported between preeclamptic women and women with normal pregnancy. Placental mRNA $D K K 1$ levels were lower in preeclamptic women compared with normal pregnant women. Placental mRNA $\beta$-catenin levels showed no significant difference between two groups.

Conclusions Our findings reported the aberrant placental mRNA DKK1 levels in patients with preeclampsia. In addition, worse preeclampsia features were associated with decreased maternal serum DKK1 levels. Hence, aberrant Wnt/ $\beta$-catenin signaling might present a plausible mechanism in preeclampsia pathogenicity. Dysregulated expression of DKK1 at gene level in the placenta but not at protein level in the maternal serum might confirm the notion that preeclampsia is a type of placenta-derived disease.

\section{ZUSAMMENFASSUNG}

Hintergrund Präeklampsie ist immer noch eine der wesentlichen Ursachen für die perinatale und mütterliche Mortalität und Morbidität weltweit. Wnt/ $\beta$-Catenin-Signalisierung spielt bekanntlich eine wichtige Rolle bei der Entwicklung der Pla- 
zenta, und Dickkopf-1 (DKK1) ist ein zentraler Regulator dieses Transduktionswegs. Ziel dieser Studie war es, die DKK1Konzentrationen im mütterlichen Serum und die plazentären Konzentrationen von DKK1 und $\beta$-Catenin in Frauen mit Präeklampsie und in Frauen mit normaler Schwangerschaft bei der Geburt zu vergleichen.

Methoden Es wurden insgesamt 30 Frauen mit Präeklampsie und 30 Frauen mit normalem Schwangerschaftsverlauf in die Studie aufgenommen. DKK1-Konzentrationen im mütterlichen Serum wurden mit ELISA gemessen. Die plazentären mRNA-Konzentrationen von DKK1 und $\beta$-Catenin wurden mithilfe von RT-PCR ermittelt.

Ergebnisse Niedrige DKK1-Konzentrationen im mütterlichen Serum waren mit schlechteren mütterlichen und fötalen Komplikationen assoziiert, darunter HELLP-Syndrom, einem oder mehreren pathologischen Symptomen bzw. der Diagnose einer intrauterinen Wachstumsretardierung. Es wurde kein signifikanter Unterschied in den DKK1-Konzentrationen im mütterlichen Serum zwischen Frauen mit Präeklampsie und
Frauen mit normaler Schwangerschaft festgestellt. Die plazentären mRNA-DKK1-Konzentrationen waren niedriger bei Frauen mit Präeklampsie verglichen mit den Konzentrationen bei Frauen mit normaler Schwangerschaft. Es fanden sich aber keine signifikanten Unterschiede in den plazentären mRNA- $\beta$ Catenin-Konzentrationen zwischen den beiden Gruppen.

Schlussfolgerungen Unsere Ergebnisse weisen auf abnormale plazentäre mRNA-DKK1-Konzentrationen bei Patientinnen mit Präeklampsie hin. Dazu kommt noch, dass ein schlechterer Verlauf der Präeklampsie mit verminderten DKK1-Konzentrationen im mütterlichen Serum assoziiert ist. Dies weist darauf hin, dass eine abnormale Wnt/ $\beta$-CateninSignalisierung einen plausiblen Mechanismus bei der Pathogenität von Präeklampsie darstellen könnte. Die Dysregulierung der Expression von DKK1 auf der genetischen Ebene in der Plazenta, nicht aber auf der Ebene des Proteins im mütterlichen Serum könnte die These untermauern, dass Präeklampsie eine Art plazentabedingte Erkrankung ist.

\section{Background}

Preeclampsia (PE) is a major cause of maternal and perinatal morbidity and mortality, affecting 2-8\% of all pregnancies worldwide [1]. PE is characterized by hypertension, proteinuria and other organ dysfunction, occurring at any time after the 20th week of pregnancy [2]. Different theories have been proposed to explain the PE etiology. Abnormal implantation, aberrant trophoblastic invasion of spiral arteries of the myometrium, which causes deficient vascular placental development are the most discussed pathophysiology of PE [3]. However, the trigger for poor placental development and the subsequent cascade of events is multifactorial and still not well understood [4].

It has been shown that placentation is regulated by different factors including multiple signaling pathways such as Wnt/ $\beta$-catenin cascade [5]. Wnt/ $\beta$-catenin signaling is evolutionarily conserved. It controls a wide range of developmental processes. Activation of this cascade is initiated when a Wnt ligand protein binds to Frizzled receptors and their co-receptors (LRP5/6) resulting in transmitting the signal into the cytoplasm. This signal leads to $\beta$-catenin stabilization and its cytoplasmic accumulation. The accumulated $\beta$-catenin is translocated into the nucleus to activate the transcription of numerous genes controlling cell cycle, differentiation and invasion such as c-myc and cyclin D1 [6]. Dickkopf (DKK) family proteins are extracellular regulators of Wnt/ $\beta$-catenin signaling. DKK1 is a secreted protein that has been shown to modulate $\mathrm{Wnt} / \beta$-catenin pathway activity via degradation of cytosolic $\beta$-catenin and reduction of nuclear $\beta$-catenin-dependent gene transcription $[7,8]$.

$W n t / \beta$-catenin signaling is involved in endometrial hemostasis and normal uterine function [9-12], as well as in different gestational disorders such as aberrant trophoblastic invasion and placental organoid [13-14]. Wnt ligands and DKK1 were found to be expressed in endometrial cells in a menstrual cycle-dependent manner [15]. In addition, Sonderegger and colleagues iden- tified different expression pattern of many Wnt ligands and frizzled receptors in human placenta and its different trophoblast subtypes. Their results suggested that several different Wnt signalling pathways could be active in human placenta depending on the cell-specific expression and distribution of individual Wnts and FZD receptors [16].

Abnormal Wnt/ $\beta$-catenin signaling revealed to be involved in the pathogenesis of various diseases including cancer [17]. Trophoblasts share some biological characteristics with cancer cells such as migration and invasion, yet in a highly organized and precisely controlled spatiotemporal manner [18]. Therefore, the role of Wnt/ $\beta$-catenin signalling in trophoblast development has been investigated and results proved the involvement of this cascade in the etiology of PE [19].

Aberrant Wnt/B-catenin signaling could serve as a pathologic mechanism for PE inception and progression. This study was designed to explore the role of DKK1 as a negative regulator of $W n t / \beta$-catenin signaling in PE. Therefore, we have investigated the expression levels of secreted DKK1 and placental mRNA levels of $D K K 1$ and $\beta$-catenin in women with PE comparing to women with normal pregnancy.

\section{Material and Methods}

\section{Ethical approval}

This study was carried out at the Department of Gynecology and Reproductive Medicine of University Medical School of Saarland in Germany. Our Study was approved by the local Ethic Committee of the Medical Association of the Saarland (Decision number 249/13) and was in accordance with the Declaration of Helsinki. All study participants were properly informed and provided a written consent prior to their participation. 


\section{Study cases}

We designed a prospective cohort study and included 60 pregnant women. The patient collective was divided into two equal sub-collectives: 30 women with PE and 30 women with normal pregnancy (NP) as a control group.

Diagnosis of PE, definition of PE severity, HELLP syndrome and intrauterine growth retardation (IUGR) determination were assessed following the German national guideline for hypertensive diseases during pregnancy [20]. PE was defined as blood pressure $\geq 140 / 90 \mathrm{mmHg}$ with proteinuria $>300 \mathrm{mg} / 24 \mathrm{~h}$ occurring after completing 20th pregnancy week. Severe PE is defined as PE with the presence of at least one of the following criteria: blood pressure $\geq 160 / 110 \mathrm{mmHg}$, progressive renal insufficiency (creatinine $\geq 0.9 \mathrm{mg} / \mathrm{dl}$ ), impaired liver function (elevated transaminases, upper abdominal pain), thrombocytopenia, pulmonary edema, central nervous system dysfunction abnormalities (severe headache, blurred vision), or IUGR. IUGR was determined by the presence of fetal estimated weight $<10$ th percentile and pathological Doppler of the umbilical and/or uterine artery. HELLP syndrome represents a type of $\mathrm{PE}$ with severe features in which elevated liver enzymes (transaminases elevation $>35 \mathrm{U} / \mathrm{I}$ ), low platelet count (thrombocytes $<100000 / \mu \mathrm{l}$ ) and hemolysis (low serum haptoglobin $[\leq 25 \mathrm{mg} / \mathrm{dl}]$ or lactate dehydrogenase [LDH] $\geq 2$ times the upper level of normal range [0-262 U/I]) were the predominant features. PE patients with gestational age $\geq 34$ weeks were classified as late onset PE.

The control group consisted of age-matched women without PE symptoms according to the German national guideline for hypertensive diseases during pregnancy [20].

All participants were older than 18 years. The exclusion criteria included known chronic systemic diseases (such as cardiac, renal or lung disease), inflammatory or infectious disease, gestational diabetes mellitus or type 2 diabetes mellitus, and gestations complicated by chromosomal or fetal anomalies. Giving birth $\geq 37$ gestational week was defined as term birth; delivery $<37$ weeks was considered as preterm birth.

Clinical data and laboratory test results were collected from each patient's electronic medical record using Viewpoint version 5, SAP, and GE Voluson E8 Ultrasound systems.

\section{Sample collection}

Blood samples were collected at the time of delivery. A total of $5 \mathrm{ml}$ venous blood was drawn in S-Monovette serum-gel tubes (Sarstedt, Germany). The samples were centrifuged at $1000 \mathrm{~g}$ for $10 \mathrm{~min}$ at $4^{\circ} \mathrm{C}$. The supernatant serum was transferred in aliquots to $1.5 \mathrm{ml}$ Eppendorf tubes and frozen at $-80^{\circ} \mathrm{C}$ until analysed.

Placental tissues were obtained within 15 min after delivery. Samples (approximately $1 \mathrm{~cm}^{3}$ each) were dissected from three different sites of the maternal side under aseptic conditions. Biopsy cores were snap frozen in liquid nitrogen and further stored at $-80^{\circ} \mathrm{C}$ until analysis.

\section{Serum analysis}

Maternal secreted levels of DKK1 were measured using a sandwich enzyme-Linked immunosorbent Assay (ELISA) kit (Human DKK1 Quantikine ELISA Kit, catalog no. DKK100B, R\&D Systems, Germany). Measurement procedures were done following the manu- facturer's instruction manual. All measurements were performed in duplicate. Optical density was measured at $450 \mathrm{~nm}$ and referenced to $570 \mathrm{~nm}$ on a 96-well microplate reader (Sunrise-Tecan, Life Science) and protein levels were obtained with a four-parameter logistic curve fitted against a standard curve and multiplied by the dilution factor using Magellan 7.2 Ink Data Analysis Software (Life Science-Tecan).

\section{Tissue analysis}

\section{RNA extraction and cDNA synthesis}

A maximum amount of $20-25 \mathrm{mg}$ frozen placenta tissues were distributed and homogenized in $300 \mu$ of RNeasy lysis buffer (Qiagen, Valencia, CA, USA) using Tissuelyser LT Adapter and stainless steel beads from Qiagen. RNA extraction was performed according to the manufacturer's instructions using RNeasy MiniKit (Qiagen, Valencia, CA, USA). Thereafter, Ambion TURBO DNA-free DNase kit (Life Technologies GmbH, Darmstadt, Germany) was used to remove contaminating DNA and to subsequently remove the DNase and divalent cations from extracted RNA samples. RNA purity and concentration were measured using Thermo Scientific NanoDrop 2000. In addition, further detecting of RNA integrity was done using Agilent RNA 6000 Nano Reagents Part I (Agilent Technologies, Waldbronn, Germany) and Bioanalyser Agilent 2100 from Agilent Technologies. Reverse transcribed complementary DNA (cDNA) was synthesized using High Capacity cDNA Reverse Transcription Kit (Applied Biosystem, Foster City, CA, USA) as described by the manufacturer.

\section{RT-PCR test}

PCR efficiency between $90 \%$ and $100 \%$ was established to confirm that RT-PCR results will not be influenced by amplification of contaminating DNA in the RNA samples. All samples were diluted to obtain a concentration of $10 \mathrm{ng}$ cDNA. Samples were tested using TaqMan Gene Expression Assays by Life Technologies (Dickkopf WNT signaling pathway inhibitor 1 [DKK1], [catalog no. Hs00183740_m1], Catenin beta1 [CTNNB1] [catalog no. Hs00355045_m1], and Actin beta [ACTB] [caltalog no. Hs03929097_m1]) and Applied Biosystems 7500 Fast Real-Time PCR System. All samples were tested in triplicate and no template control (NTC) was included in each run. Results were analyzed using the 7500 Software v.2.0.5 (Life Technologies GmbH, Darmstadt, Germany). A relative quantification $2^{-\Delta \Delta C t}$ method was used to normalize the samples with respect to the reference gene [ACTB] and obtain fold change values of PE cohort using normal pregnant women as a control group [21]. The mean value of mRNA transcripts of each participant was set as one for each tested gene.

\section{Statistical analysis}

Data were analyzed using SPSS version 21 (IBM, Armonk, NY, USA). Median and range were used for the descriptive analysis of non-parametric continuous variables and absolute and relative frequencies were used for the categorical variables. The null hypothesis was tested against its alternative using either non-parametric Mann-Whitney-U-Test for continuous variables or $\mathrm{X}^{2}$ Test for categorical variables. Correlations between two continuous variables were evaluated using the non-parametric Spearman cor- 
- Table 1 Clinical characteristics of study subjects.

\begin{tabular}{|c|c|c|c|}
\hline Characteristic & Women with NP $(n=30)$ & Women with PE $(n=28)$ & p-value \\
\hline Maternal age (years) ${ }^{\dagger}$ & $32(23-42)$ & $32(24-42)$ & NS \\
\hline Gestational age at sampling (weeks) $^{\dagger}$ & $38+3([37+1]-[39+4])$ & $35+3([26+4]-[40+2])$ & $<0.0001$ \\
\hline Gravida*\# & $\begin{array}{l}\text { Primigravida: } \mathrm{n}=5 \\
\text { Secundigravida: } \mathrm{n}=13 \\
\text { Multigravida } \mathrm{n}=12\end{array}$ & $\begin{array}{l}\text { Primigravida: } \mathrm{n}=19 \\
\text { Secundigravida: } \mathrm{n}=6 \\
\text { Multigravida } \mathrm{n}=3\end{array}$ & $<0.0001$ \\
\hline Para*\# & $\begin{array}{l}\text { Nulliparous: } \mathrm{n}=0 \\
\text { Primiparous: } \mathrm{n}=6 \\
\text { Multiparous: } \mathrm{n}=24\end{array}$ & $\begin{array}{l}\text { Nulliparous: } \mathrm{n}=1 \\
\text { Primiparous: } \mathrm{n}=21 \\
\text { Multiparous: } \mathrm{n}=6\end{array}$ & $<0.0001$ \\
\hline $\operatorname{BMI}\left(\mathrm{kg} / \mathrm{m}^{2}\right)^{\dagger}$ & $31.8(20.2-47.9)$ & $33.8(24.8-58.1)$ & 0.028 \\
\hline Systolic blood pressure $(\mathrm{mmHg})^{\dagger}$ & $112(85-144)$ & $147(126-240)$ & $<0.0001$ \\
\hline Diastolic blood pressure $(\mathrm{mmHg})^{\dagger}$ & $66(50-89)$ & $90(69-120)$ & $<0.0001$ \\
\hline Urine protein $(\mathrm{mg} / 24 \mathrm{~h})^{\dagger}$ & 0 & $800(180-9020)^{\Phi}$ & $<0.0001$ \\
\hline Symptoms*,** & $\begin{array}{l}\text { Absent: } \mathrm{n}=15 \\
\text { Existent: } \mathrm{n}=15\end{array}$ & $\begin{array}{l}\text { Absent: } \mathrm{n}=9 \\
\text { Existent: } \mathrm{n}=19\end{array}$ & NS \\
\hline HELLP syndrome $(n)(\%)^{\ddagger}$ & $0(0 \%)$ & $5(18 \%)$ & 0.021 \\
\hline Birthweight $(\mathrm{g})^{\dagger}$ & $3375(2135-4550)$ & $2290(480-3880)$ & $<0.0001$ \\
\hline Preterm vs. term infants* & $\begin{array}{l}\text { Preterm: } \mathrm{n}=0 \\
\text { Term: } \mathrm{n}=30\end{array}$ & $\begin{array}{l}\text { Preterm: } \mathrm{n}=17 \\
\text { Term: } \mathrm{n}=11\end{array}$ & $<0.0001$ \\
\hline 1-min Apgar* & $\begin{array}{l}7-10: n=28 \\
<7: n=2\end{array}$ & $\begin{array}{l}7-10: n=19 \\
<7: n=8\end{array}$ & 0.013 \\
\hline 5-min Apgar* & $\begin{array}{l}7-10: n=30 \\
<7: n=0\end{array}$ & $\begin{array}{l}7-10: n=26 \\
<7: n=1\end{array}$ & NS \\
\hline 10-min Apgar* & $\begin{array}{l}7-10: n=30 \\
<7: n=0\end{array}$ & $\begin{array}{l}7-10: n=26 \\
<7: n=1\end{array}$ & NS \\
\hline IUGR neonates, $\mathrm{n}(\%)^{\ddagger}$ & $0(0 \%)$ & $9(32 \%)$ & 0.001 \\
\hline
\end{tabular}

relation coefficient and the corresponding test of the null hypothesis that the correlation coefficient is equal to zero. All statistical tests were performed at a two-sided comparison-wise significance level of $5 \%$. As appropriate for exploratory studies no adjustments for multiple testing was performed.

\section{Results}

The data of two PE patients had to be removed from the analysis after withdrawal of their consent forms. Clinical characteristics of study participants are summarized in - Table 1. Briefly, cases with NP had decreased BMI and increased gravidity and parity rate compared with PE cases. Moreover, PE was associated with higher incidence of HELLP syndrome and poorer birth outcomes including lower birthweight, preterm birth, and IUGR in 32\% (9/28) of included cases. In addition, PE cases with symptoms included 14 cases with edema, 2 cases with epigastric pain, 2 cases with headache, 1 case with headache and edema and 1 case with headache and epigastric pain. On the other hand, NP cases included 15 women with mild edema and 15 women with no symptom.

\section{Maternal serum DKK1 levels}

DKK1 levels did not correlate with maternal age or BMI in both study groups and in the complete study cohort (all $p>0.05$ ). We found no significant difference in maternal serum DKK1 levels between PE patients and women with NP (Mean [Average]: 2320 [985-4161] pg/ml vs. [1070-4717] pg/ml respectively, $\mathrm{p}>0.05$ ) ( $\triangleright$ Fig. 1). Similar observations were made comparing maternal serum DKK1 levels in PE cases and NP cases of matched gestational age ( $\geq 35$ weeks) (Mean [Range]: 2344 [1764-3470] pg/ml in $15 \mathrm{PE}$ cases vs. 2403 [1070-4717] pg/ml in $30 \mathrm{NP}$ cases, $p>0.05$ ). However, we found that PE women diagnosed with one or more symptoms (headache, severe edema, vaginal bleeding, epigastric pain, and vision changes) had decreased maternal serum DKK1 levels compared with PE cases with no clinical symptoms ( $\triangleright$ Fig. 2 a). NP women showed no differences in maternal serum DKK1 levels comparing cases diagnosed with one or more symptoms and cases with no symptom ( $\bullet$ Fig. $\mathbf{2}$ b).

We also correlated between serum DKK1 levels and PE features ( $\triangleright$ Table 2). Decreased serum DKK1 levels were associated with HELLP syndrome diagnosis (Mean [Range]: 1710 [985-2565] pg/ 
$\mathrm{ml}$ in five cases with HELLP vs. 2361 [1644-4161] $\mathrm{pg} / \mathrm{ml}$ in 23 cases without HELLP, $\mathrm{p}=0.027$ ). In addition, cases with IUGR neonates had lower serum DKK1 levels compared with cases with normal IUG neonates (Mean [Range]: 1884 [985-2872] pg/ml vs. 2377 [1764-4161] pg/ml respectively, $\mathrm{p}=0.027)$. We found no significant correlation between serum DKK1 levels and PE severity or onset ( $\triangleright$ Table 2 ).

\section{Placental mRNA levels of $D K K 1$ and $\beta$-catenin}

Our RT-PCR results showed that PE cases had significantly lower placental DKK1 mRNA levels compared with NP cases (Mean [Range] $\Delta C_{\mathrm{t}}: 6.29$ [3.48-7.71] vs. 5.43 [2.67-7.54] respectively, $\mathrm{p}=0.033$ ) ( $\triangleright$ Fig. $3 \mathrm{a}$ ). Using $2^{-\Delta \Delta \mathrm{Ct}}$ equation, this reduction was estimated by $38 \%$. By comparing DKK1 mRNA levels in PE cases and NP cases of matched gestational age ( $\geq 35$ weeks), we reported also that PE cases had significantly lower placental DKK1 mRNA levels compared with NP cases (Mean [Range] $\Delta C_{\mathrm{t}}: 6.37$ [3.48-7.71] in $15 \mathrm{PE}$ cases vs. 5.43 [2.67-7.54] in $30 \mathrm{NP}$ cases, $\mathrm{p}=0.046)$.

In addition, placental $\beta$-catenin mRNA levels in PE cases were also lower than values in NP cases, but the difference was not statistically significant (Mean [Range] $\Delta C_{\mathrm{t}}: 0.9$ [-2.36-1.83] vs. 0.62 [0.01-1.89] respectively, $p=0.054)$ ( $\triangleright$ Fig. 3 b).

Moreover, we tested the correlation of placental DKK1 mRNA levels with maternal serum DKK1 levels and with placental $\beta$-catenin mRNA levels in PE and NP cases and results reported no significant results.

\section{Discussion}

The clinical diagnostic and prognostic value of serum levels of DKK1 in human cancers is well documented in the literature [22, 23]. Up to now, however, little is known about circulating levels of DKK1 in PE. In the current study, we investigated maternal serum DKK1 levels in PE and NP women. The results revealed no significant differences between the two groups. In addition, we reported no differences between women with early-onset PE (11 cases) and women with late-onset PE (17 cases). Our results are in line with the findings of Ueland et al., who documented no significant differences in circulating DKK1 levels in a cohort consist-

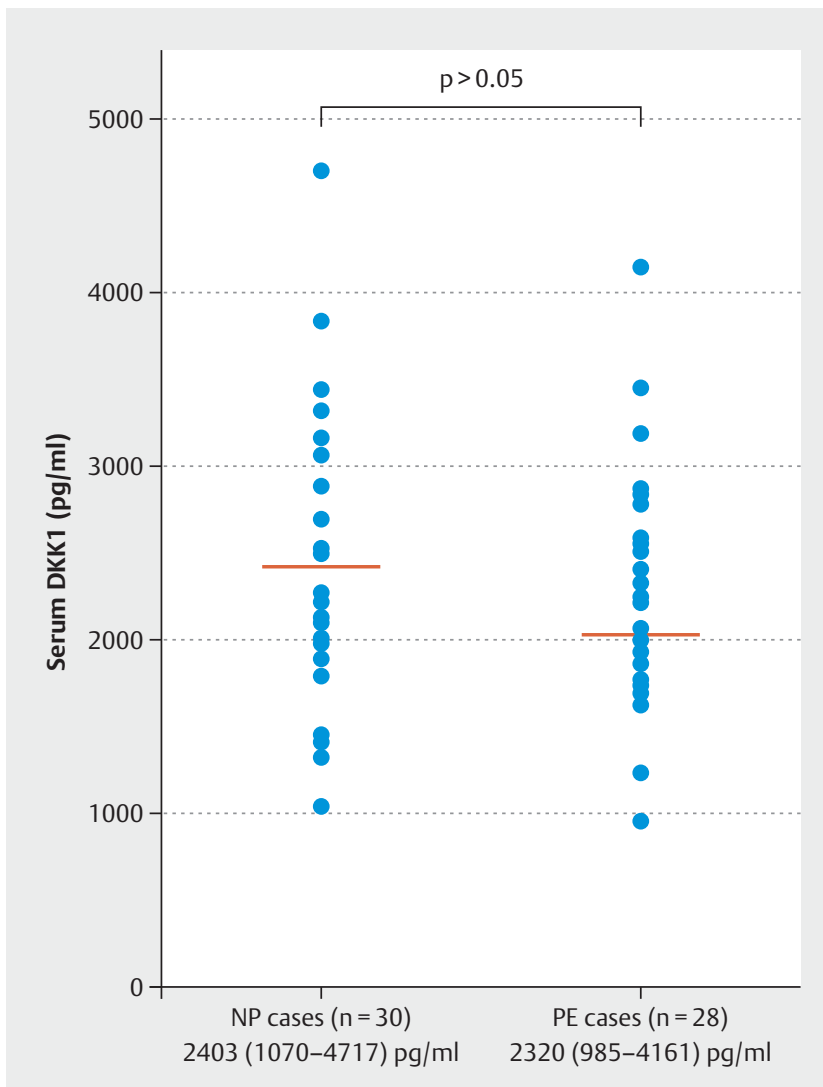

- Fig. 1 Maternal serum DKK1 levels in NP and PE cases. No statistically significant differences in maternal serum DKK1 levels were found between PE cases and NP cases. Results are presented as Mean (Range). p-value is tested using Mann-Whitney-U-test. $\mathrm{n}$ : number of cases.

ing of 61 women with NP and 34 women with PE at term (weeks 35-36) [24]. On the contrary, Tayyar and colleagues showed increased serum DKK1 levels in women with early-onset PE (27 cases) compared with NP women (27 cases). Nevertheless, lateonset PE women (26 cases) showed no differences compared with

- Table 2 Correlation of maternal serum DKK1 levels with preeclampsia features.

\begin{tabular}{|l|l|l|}
\hline Feature & Cases & Serum DKK1 (pg/ml) \\
\hline PE severity & $\begin{array}{l}\text { Mild PE }(n=14)^{*} \\
\text { Severe PE }(n=14)\end{array}$ & $2321(1256-3470)$ \\
\hline HELLP syndrome & Cases without HELLP $(n=23)$ & $2306(985-4161)$ \\
\hline Cases with HELLP $(n=5)$ & $2361(1644-4161)$ \\
\hline PE onset & Late onset $(n=17)$ & $1710(985-2565)$ \\
\hline IUGR & Early onset $(n=11)$ & $2267(985-3470)$ \\
\hline & IUGR neonates $(n=9)$ & $2430(1256-4161)$ \\
\hline & Normal IUG neonates $(n=19)$ & $2377(1764-4161)$ \\
\hline
\end{tabular}



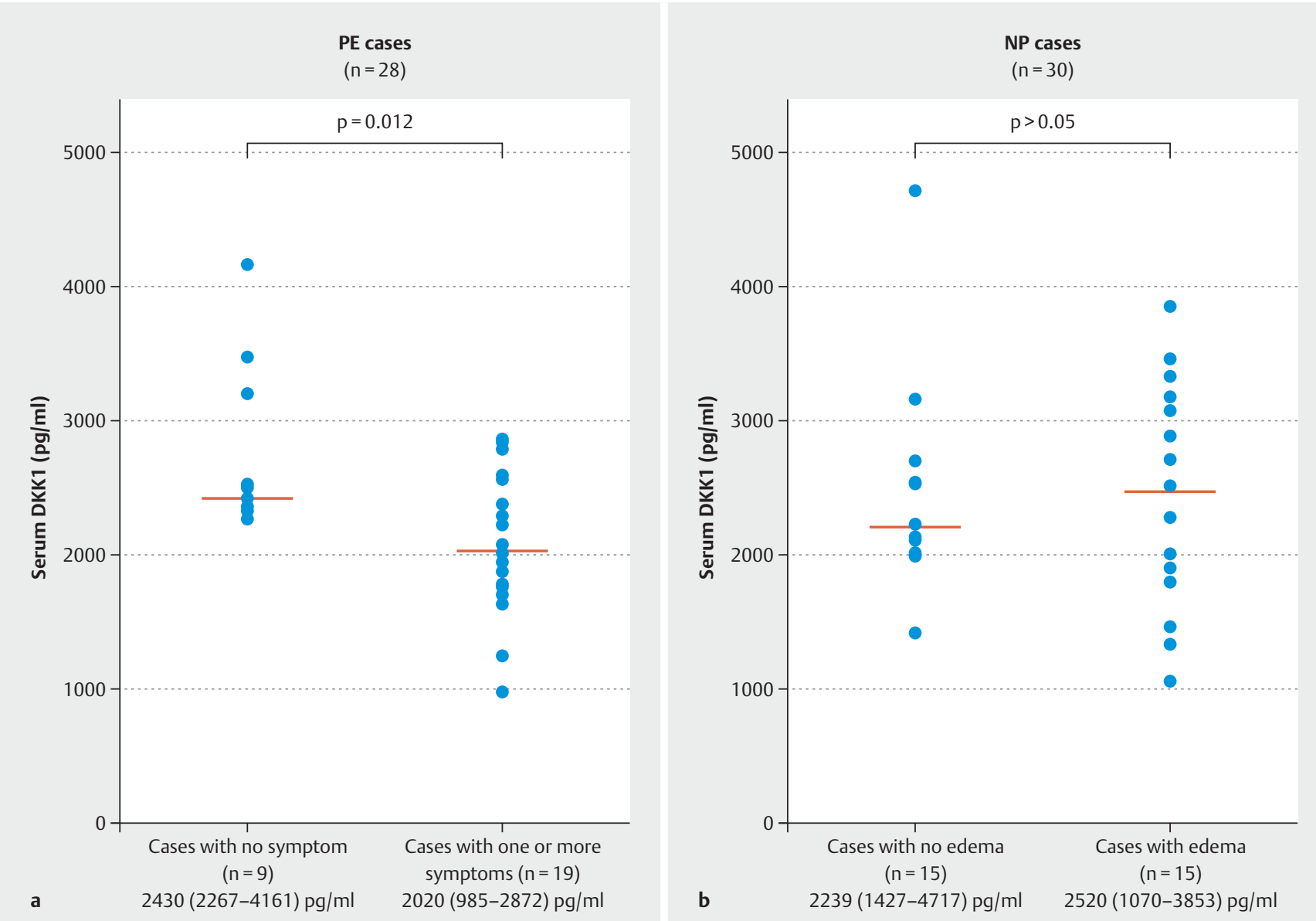

- Fig. 2 Correlation between maternal DKK1 serum levels and existence with symptoms in PE and NP women. a PE women with diagnosis of one or more symptoms had decreased maternal serum DKK1 levels compared with PE cases with no symptom. b NP women showed no differences in maternal serum DKK1 levels between cases diagnosed with edema and cases without edema. Results are presented as Mean (Range). p-value is tested using the non-parametric Mann-Whitney-U-test. n: number of cases.

NP women or early-onset PE women [25]. Moreover, their results revealed that maternal serum DKK1 levels had significant negative correlation with age but not BMI or gestational age at the time of blood sampling. Our data reported no significant correlation between serum DKK1 levels and any of these three parameters. In the study of Tayyar and colleagues, authors did not specify which cases were included for the correlation analysis between serum DKK1 levels and clinical parameters. In our study, the analysis was performed separately, for all study cases as one cohort, for NP cohort, and for PE cohort. None of these analyses revealed statistically significant correlations. Inconsistency across studies could be due to the differences in study parameters including number of tested cases, clinic-pathological characteristics of study subjects, and time of sample drawing. In addition, we assume that the notable overlapping in serum DKK1 values between tested groups enables defining a clear cut-off value of this parameter, which may in turn affect its potential as a screening biomarker in PE. An apparent dichotomy in DKK1 activity as a clinical diagnostic and prognostic biomarker in various types of cancer was also reported by different studies $[26,27]$.
Vascular endothelial dysfunction is responsible for the clinical signs observed in women with PE. Impaired trophoblastic invasion of spiral arteries leads to chronic placental ischemia and oxidative stress, which in turn cause fetal complications and induce release of different circulating substances resulting in defective hepatic endothelium and cerebral endothelium responsible for onset of HELLP syndrome and cerebral edema respectively [28]. In kidneys, aberrant endothelial function induces vascular hyperpermeability associated with low serum albumin causes edema [29]. DKK1 has been shown to play an important role in endothelial dysfunction in different diseases [30,31]. Therefore, DKK1 could be linked to the clinical symptoms resulting from the endothelial dysfunction in PE. In this study, we found that the diagnosis of one or more symptoms was associated with decreased maternal serum DKK1 levels in PE women. On the other hand, NP women with mild edema showed no differences in serum DKK1 levels compared with NP women without edema. Moreover, decreased maternal serum DKK1 levels were associated with fetal complication presented by IUGR diagnosis. 


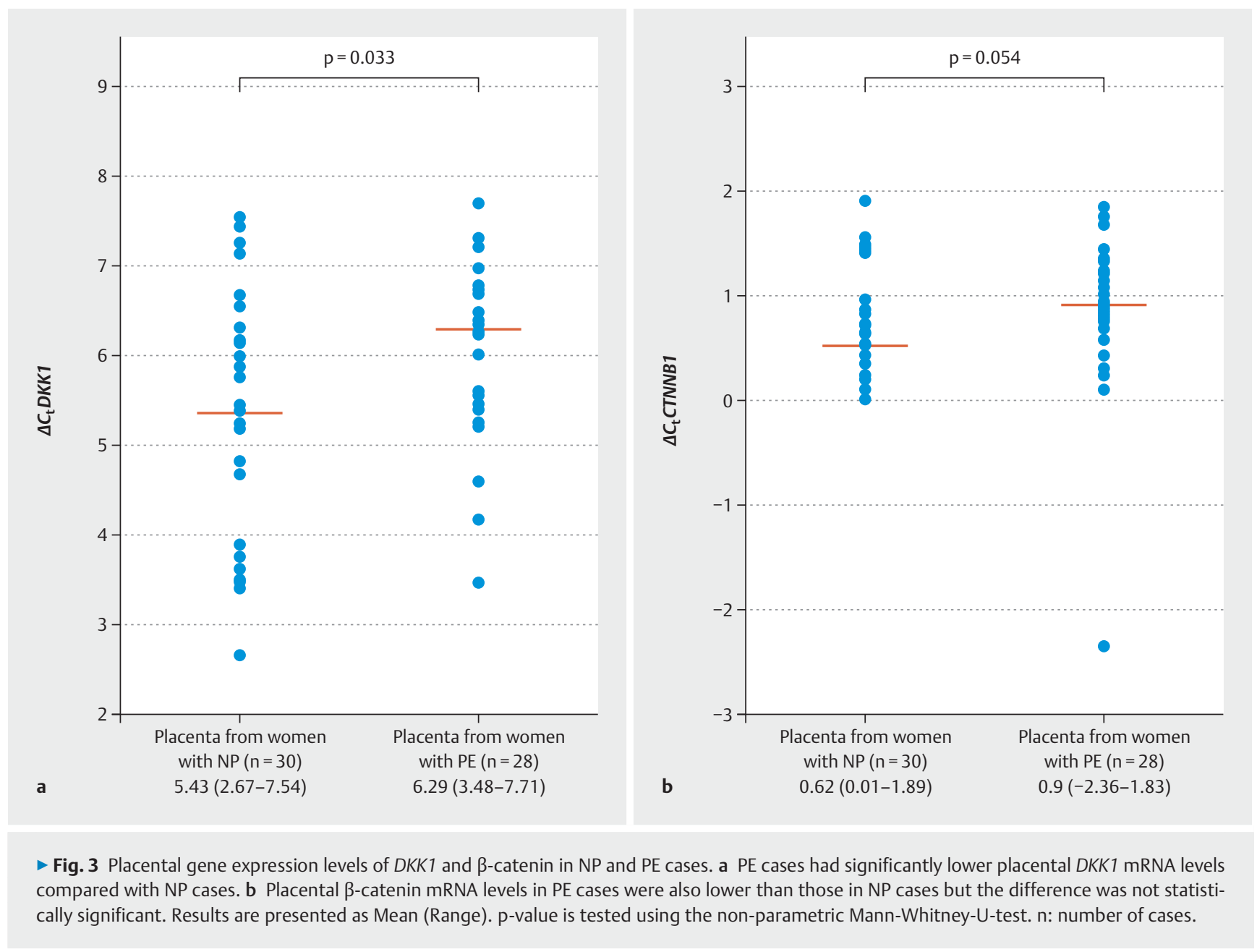

We also found that maternal serum DKK1 levels were changed in regard to HELLP syndrome diagnosis but not to the degree of disease severity. Women with gestational hypertension progress to mild preeclampsia and severe preeclampsia at rates of $46 \%$ and $9.6 \%$, respectively [32]. HELLP syndrome is regarded as a more severe form of PE occuring in 10 to $20 \%$ of cases with severe $\mathrm{PE}$ and in 0.5 to $0.9 \%$ of all pregnancies [33]. The relationship between severe PE and HELLP syndrome remains controversial. Kinay et al. showed that severe PE and HELLP syndrome cases presented different maternal outcomes and similar perinatal outcomes at $<34$ and $\geq 34$ weeks of gestation [34]. In our study, the comparison of maternal serum DKK1 levels between severe PE and HELLP syndrome cases was not performed because of the small number of cases diagnosed with HELLP syndrome without extreme high blood pressure or elevated proteinurea concentration.

Further, we detected placental gene expression levels of DKK1 in both study groups and found that PE cases had significantly 38\% lower placental DKK1 transcript levels compared with NP women. We also detected placental transcript levels of $\beta$-catenin in order to investigate the influence of the reduction in DKK1 transcript levels on Wnt signal activity. We found that placental transcript levels of $\beta$-catenin in PE women were lower than levels in NP women but the difference was not statistically significant. Few studies have examined placental gene and/or protein expression levels of DKK1 and $\beta$-catenin in PE. Zhang and co-workers analysed DKK1 and $\beta$-catenin expression in third trimester placentas from NP women and women with severe PE. They found that mRNA and protein expression levels of $\beta$-catenin were decreased and those of DKK1 were increased in PE placentas compared with NP placentas [35]. These observations were later confirmed by Wang et al. Their study showed that women with severe PE had increased placental DKK1 expression and decreased placental $\beta$-catenin expression at protein level compared with NP women. In addition, placental $\beta$-catenin mRNA levels were also reduced in $P E$ cases [36]. Placental gene and/or protein expression levels of DKK1 and $\beta$-catenin in PE were also detected according to disease onset. In a recent comparative study, placental mRNA DKK1 levels were found to be significantly decreased in preterm NP women compared to term NP women and early-onset PE women. The last two groups showed no significant differences [37]. On the other hand, $\mathrm{Na}$ and colleagues demonstrated decreased placental protein expression of DKK1 and increased placental protein expression of $\beta$-catenin in early-onset PE women and in late-onset PE women compared with NP women [38]. The incompatibility between the findings of all the previously mentioned studies includ- 
ing ours could be due to the different timing of sample acquisition and/or to the absence of normalization using trophoblast subtype-specific/stromal markers as placenta from women with PE may have a different composition of different trophoblast subtypes versus stroma.

Moreover, our results showed no causal relationship between gene and protein expression levels of DKK1 in both study groups. DKK1 as a secretory protein could undergo different types of posttranslational modifications in it or in its ligands, which in turn might affect its function. DKK1 is a downstream target of Wnt/ $\beta$-catenin cascade performing a regulatory effect through negative feedback loop [39]. However, we found no significant correlation between placental DKK1 mRNA levels and placental $\beta$-catenin mRNA levels in our study cohort. This might be due, in part, to the small number of tested cases and the lack of detecting placental protein localization and expression levels of DKK1 and $\beta$-catenin. Concurrent detection of gene and protein expression levels of target molecules enable more insight into the molecular basis of $W n t / \beta$-catenin in the reciprocal interactions between the mother and the fetus during normal and preeclamptic pregnancy.

\section{Conclusions}

This study aimed to detect the role of DKK1 in PE. Based on a quantitative analysis of maternal serum levels and placental gene levels in PE women as well as in NP women, we conclude that DKK1 could be involved in PE pathogenicity. Dysregulated expression of DKK1 at gene level in the placenta but not at protein level in the maternal serum might confirm the notion that preeclampsia is a type of placenta-derived disease. More serious PE features were associated with decreased maternal serum DKK1 levels. However, further large-scale and multicenter studies using blood samples at different times (at pregnancy diagnosis, at PE diagnosis in affected women, and at delivery) are warranted to demonstrate the potential of serum DKK1 levels in PE.

\section{Conflict of Interest}

The authors declare that they have no conflict of interest.

\section{References}

[1] Townsend R, O'Brien P, Khalil A. Current best practice in the management of hypertensive disorders in pregnancy. Integr Blood Press Control 2016; 9: 79-94. doi:10.2147/IBPC.S77344

[2] Peres GM, Mariana M, Cairrão E. Pre-Eclampsia and Eclampsia: An Update on the Pharmacological Treatment Applied in Portugal. J Cardiovasc Dev Dis Actions 2018; 5: 3. doi:10.3390/jcdd5010003

[3] Meekins JW, Pijnenborg R, Hanssens M et al. A study of placental bed spiral arteries and trophoblast invasion in normal and severe pre-eclamptic pregnancies. Br J Obstet Gynaecol 1994; 101: 669

[4] Knöfler M, Haider A, Saleh L et al. Human placenta and trophoblast development: key molecular mechanisms and model systems. Cell Mol Life Sci 2019; 76: 3479-3496

[5] Knöfler M, Pollheimer J. Human placental trophoblast invasion and differentiation: a particular focus on Wnt signaling. Front Genet 2013. doi:10.3389/fgene.2013.00190
[6] Clevers H. Wnt/ $\beta$-Catenin Signaling in Development and Disease. Cell 2006; 127: 469-480

[7] Niehrs C. Function and biological roles of the Dickkopf family of Wnt modulators. Oncogene 2006; 25: 7469-7481

[8] Matoba K, Mihara E, Tamura-Kawakami K et al. Conformational freedom of the LRP6 ectodomain is regulated by $\mathrm{N}$-glycosylation and the binding of the Wht antagonist Dkk1. Cell Rep 2017; 18: 32-40

[9] Wang $\mathrm{Y}$, van der Zee M, Fodde R et al. Wnt/B-catenin and sex hormone signaling in endometrial homeostasis and cancer. Oncotarget 2010; 1 : 674-684

[10] Fan X, Krieg S, Hwang JY et al. Dynamic regulation of Wnt7a expression in the primate endometrium: implications for postmenstrual regeneration and secretory transformation. Endocrinology 2012; 153: 10631069

[11] Atli MO, Guzeloglu A, Dinc DA. Expression of wingless type (WNT) genes and their antagonists at mRNA levels in equine endometrium during the estrous cycle and early pregnancy. Anim Reprod Sci 2011; 125: 94-102

[12] Dunlap KA, Filant J, Hayashi K et al. Postnatal deletion of Wnt7a inhibits uterine gland morphogenesis and compromises adult fertility in mice. Biol Reprod 2011; 85: 386-396

[13] Meinhardt G, Haider S, Haslinger $P$ et al. Wnt-dependent T-cell factor-4 controls human etravillous trophoblast motility. Endocrinology 2014; 155: $1908-1920$

[14] Turco MY, Gardner L, Kay RG et al. Trophoblast organoids as a model for maternal-fetal interactions during human placentation. Nature 2018; 564: $263-267$

[15] Tulac S, Overgaard MT, Hamilton AE et al. Dickkopf-1, an inhibitor of Wnt signaling, is regulated by progesterone in human endometrial stromal cells. J Clin Endocrinol Metab 2006; 91: 1453-1461

[16] Sonderegger $\mathrm{S}$, Husslein $\mathrm{H}$, Leisser $\mathrm{C}$ et al. Complex expression pattern of Wnt ligands and frizzled receptors in human placenta and its trophoblast subtypes. Placenta 2007; 28: S97-S102

[17] Ng LF, Kaur P, Bunnag N et al. WNT Signaling in Disease. Cells 2019; 8: 826

[18] Soundararajan R, Rao AJ. Trophoblast 'pseudo-tumorigenesis': Significance and contributory factors. Reprod Biol Endocrinol 2004; 2: 15

[19] Zhang Z, Wang X, Zhang L et al. Wnt/ $\beta$-catenin signaling pathway in trophoblasts and abnormal activation in preeclampsia (Review). Mol Med Rep 2017; 16: 1007-1013

[20] Stepan H, Kuse-Fohl S, Klockenbusch W et al. Diagnosis and Treatment of Hypertensive Pregnancy Disorders. Guideline of DGGG (S1-Level, AWMF Registry No.015/018, December 2013). Geburtshilfe Frauenheilkd 2015; 75: 900-914

[21] Livak KJ, Schmittgen TD. Analysis of relative gene expression data using real-time quantitative PCR and the 2(-Delta Delta C(T)) Method. Methods 2001; 25: 402-408

[22] Wei R, Rodrìguez RA, Mullor MDMR et al. Analyzing the prognostic value of DKK1 expression in human cancers based on bioinformatics. Ann Transl Med 2020; 8: 552

[23] Li J, Gao Y, Yue W. The Clinical Diagnostic and Prognostic Value of Dickkopf-1 in Cancer. Cancer Manag Res 2020; 12: 4253-4260

[24] Ueland T, Estensen ME, Grindheim G et al. Elevated levels of the secreted wingless agonist R-spondin 3 in preeclamptic pregnancies. J Hypertens 2020; 38: 1347-1354

[25] Tayyar AT, Karakus R, Eraslan Sahin M et al. Wnt signaling pathway in early- and late-onset preeclampsia: evaluation with Dickkopf-1 and RSpondin-3 glycoproteins. Arch Gynecol Obstet 2019; 299: 1551-1556

[26] Xu H, Wu J, Chen B et al. Serum Dickkopf-1 (DKK1) is significantly lower in patients with lung cancer but is rapidly normalized after treatment. Am J Transl Res 2014; 22: 850-856

[27] Menezes ME, Talukdar S, Wechman SL et al. Dickkopf1: A tumor suppressor or metastasis promoter? Adv Cancer Res 2018; 138: 213-237 
[28] Sibai BM. Diagnosis, controversies, and management of the syndrome of hemolysis, elevated liver enzymes, and low platelet count. Obstet Gynecol 2004; 103: 981-991

[29] Karumanchi SA, Maynard SE, Stillman IE et al. Preeclampsia: a renal perspective. Kidney Int 2005; 67: 2101-2113

[30] Pontremoli M, Brioschi M, Baetta R et al. Identification of DKK-1 as a novel mediator of statin effects in human endothelial cells. Sci Rep 2018; 8: 16671

[31] Jiang S], Li W, Li Y] et al. Dickkopf-related protein 1 induces angiogenesis by upregulating vascular endothelial growth factor in the synovial fibroblasts of patients with temporomandibular joint disorders. Mol Med Rep 2015; 12: 4959-4966

[32] Barton JR, O’brien JM, Bergauer NK et al. Mild gestational hypertension remote from term: progression and outcome. Am J Obstet Gynecol 2001; 184: 979-983

[33] Tranquilli AL, Dekker G, Magee L et al. The classification, diagnosis and management of the hypertensive disorders of pregnancy: A revised statement from the ISSHP. Pregnancy Hypertens 2014; 4: 97-104
[34] Kınay T, Küçük C, Kayıkçıŏlu F et al. Severe Preeclampsia versus HELLP Syndrome: Maternal and Perinatal Outcomes at $<34$ and $\geq 34$ Weeks' Gestation. Balkan Med J 2015; 32: 359-363

[35] Zhang Z, Li H, Zhang L et al. Differential expression of beta-catenin and dickkopf- 1 in the third trimester placentas from normal and preeclamptic pregnancies: a comparative study. Reprod Biol Endocrinol 2013. doi:10.1186/1477-7827-11-17

[36] Wang $X$, Zhang Z, Zeng $X$ et al. Wnt/ $\beta$-catenin signaling pathway in severe preeclampsia. J Mol Histol 2018; 49: 317-327

[37] Zhang L, Leng M, Li Y et al. Altered DNA methylation and transcription of WNT2 and DKK1 genes in placentas associated with early-onset preeclampsia. Clin Chim Acta 2019; 490: 154-160

[38] Li N, Huang L, Li Y et al. Lin28B/miR-92b Promote the Proliferation, Migration, and Invasion in the Pathogenesis of Preeclampsia via the DKK1/ Wnt/ß-Catenin Pathway. Reprod Sci 2020; 27: 815-822

[39] Niida A, Hiroko T, Kasai M et al. DKK1, a negative regulator of Wnt signaling, is a target of the $\beta$-catenin/TCF pathway. Oncogene 2004; 23 : 8520-8526 